\title{
Occurrence and natural history of Myrmelachista Roger (Formicidae: Formicinae) in the Atlantic Forest of southeastern Brazil
}

\author{
Ocurrencia e historia natural de Myrmelachista Roger (Formicidae: Formicinae) \\ en la Selva Atlántica del sureste brasileño \\ MÁRCIA AKEMI NAKANO ${ }^{1}$, VITOR F. OLIVEIRA DE MIRANDA², DÉBORA RODRIGUES DE SOUZA ${ }^{1}$, \\ RODRIGO M. FEITOSA ${ }^{3} \&$ M. SANTINA C. MORINI ${ }^{1, *}$ \\ ${ }^{1}$ Laboratório de Mirmecologia, Universidade de Mogi das Cruzes, Postal Code 08701-970, Mogi das Cruzes, SP, Brazil \\ 2Laboratório de Sistemática Vegetal, Universidade Estadual Paulista, Postal Code 14884-900, Jaboticabal, SP, Brazil \\ ${ }^{3}$ Laboratório de Zoologia, Universidade Federal do Paraná, Postal Code 81531-980, Curitiba, Pr, Brazil \\ *Corresponding author: mscmorini@gmail.com
}

\begin{abstract}
Information on the biology of the species in Myrmelachista remains notably scarce. The objective of this study was to report the occurrence, analyze the influence of canopy cover on the number of nests in twigs in the litter describe behavioral characteristics of this genus. Hand sampling was performed on trees and twigs deposited in the litter. A total of 84 nests and seven species were found. Myrmelachista ruszkii and M. catharinae were the most frequent and abundant species. In trees, most of the nests were located at the tips of dry twigs, and these nests were probably the source of the nests found in the litter of fragments of Atlantic Forest of southeastern Brazil. Canopy cover is associated with the number of nests that were in twigs.
\end{abstract}

Key words: canopy, dense ombrophilous forest, polydomy, reproduction, tree species.

\section{RESUMEN}

Myrmelachista es un género neotropical de hormigas arborícolas que nidifican en cavidades de troncos y ramas. El conocimiento sobre la biología de sus especies es escaso. Este trabajo tuvo como objetivo registrar la ocurrencia, analizar la influencia del dosel sobre el número de nidos en ramas en la cama (mezcla de hojas, ramas y tierra) que cubre la selva, y describir las características de comportamiento de Myrmelachista. Se realizaron recolectas manuales de arbóreas y en ramas depositadas en la mezcla anterior. Se encontraron 84 nidos y siete especies Myrmelachista ruszkii y $M$. catharinae fueron las más frecuentes y abundantes. En las especies arbóreas la mayoría de los nidos se localizan en las extremidades secas de las ramas estos nidos fueron probablemente el origen de los nidos que se encuentran en las camas de los fragmentos de Floresta Atlántica de la región sureste brasileña. El número de nidos en ramas estaría asociado con la cobertura arbórea.

Palabras clave: bosque ombrófilo denso, dosel, especies arbóreas, polidomia, reproducción.

\section{INTRODUCTION}

The genus Myrmelachista is typically neotropical with 69 species described from southern Mexico to northern Argentina (Kempf 1972, Fernández \& Sendoya 2004, Bolton et al. 2006, Longino 2006). The species of this genus forage on trees, nesting inside live stems (Longino 2006) and may develop mutualistic interactions with host plants, specialized domatia or feeding on extrafloral nectaries (Frederickson 2005, McNett et al. 2010) and/ or coccids (Stout 1979, Ketterl et al. 2003). Data regarding the ecology and behavior of species in the genus have been reported by Renner \& Ricklefs (1998), Frederickson (2005, 2006), Frederickson \& Gordon (2009), Edwards et al. (2009) and McNett et al. (2010). Information regarding the biology of certain species, specifically from Costa Rica, is summarized in the review by Longino (2006).

Despite the information mentioned above, the biology of the genus Myrmelachista is still considered to be poorly known in comparative 
terms (Longino 2006). The objective of this study was to (1) report the occurrence of Myrmelachista species in Atlantic Forest remnants of southeastern Brazil, (2) analyze the association between canopy cover and the number of nests in twigs in the litter and (3) describe behavioral characteristics observed during the fieldwork.

\section{METHODS}

\section{Study sites and sampling of the species in vegetation}

Colonies were recorded and collected from the vegetation and twigs found in the litter of Atlantic Forest remnants located in southeastern São Paulo state, Brazil (Fig. 1).

\section{Sampling of the species in vegetation}

The sampling was performed on a weekly basis from September 2008 to September 2009, covering all seasons of the region (Minuzzi et al. 2007), along the sunny trails. The colonies were collected from three areas of the Brazilian Atlantic forest. The sampling effort was kept constant, in terms of the number of field expeditions, length of stay $(\geq 4 \mathrm{~h})$ and number of collectors (3). Worker ants that were exiting holes in tree trunks, or foraging until five centimeters from the hole, and tips of dry twigs on alive trees were collected by hand and were transferred to vials with $70 \%$ ethanol. The presence of winged reproductive was recorded.

\section{Sampling of the nests in twigs and canopy cover}

The colonies were collected from six areas of the Brazilian Atlantic forest. The sampling was performed on a weekly basis from September to December 2010 in areas without trails and not sunny. In these months, rainfall is more intense (Minuzzi et al. 2007), and results in higher deposit twigs in the leaf litter. In each area, six $16 \mathrm{~m}^{2}$ sampling points, which were separated from one another by $50 \mathrm{~m}$, were delineated. All of the twigs of $10-30 \mathrm{~cm}$ in length were opened; those with colonies that were found on the litter surface were individually placed in plastic bags for subsequent identification. Twigs with Myrmelachista nests, workers, winged and immature individuals were counted and transferred to vials with 70 $\%$ ethanol.

The canopy cover was recorded at the center and corners of each $16 \mathrm{~m}^{2}$ plot using a Nikon D80 digital camera with a fisheye lens. The images were analyzed using the Gap Light Analyzer (GLA) software, version 2.0 (Frazer et al. 1999).

\section{Species identification}

The identification of the ant species was performed through comparison with specimens deposited in the reference collection of the Museum of Zoology, University of São Paulo (Museu de Zoologia da Universidade de São Paulo, MZUSP). Type specimens were deposited in the collection of the Laboratory of Myrmecology, University of Mogi das Cruzes (Universidade de Mogi das Cruzes, UMC) and in the MZUSP.

The identification of the plants where the Myrmelachista workers were found was performed through comparison with the collection of the Upper Tietê flora in the Herbarium Mogiense (Herbário Mogiense, HUMC) at the University of Mogi das Cruzes. For that purpose, fertile or sterile branches were collected. Type specimens were deposited in the HUMC.

\section{Data analysis}

The abundances of adults and immature individuals in the twigs were compared using Mann-Whitney test. The association between canopy cover and the number of nests was determined using scatter plots and Spearman correlation. The level of significance was $\alpha=0.05$.

\section{RESULTS}

Seven Myrmelachista species were recorded in a total of 41 nests in 20 species of live trees

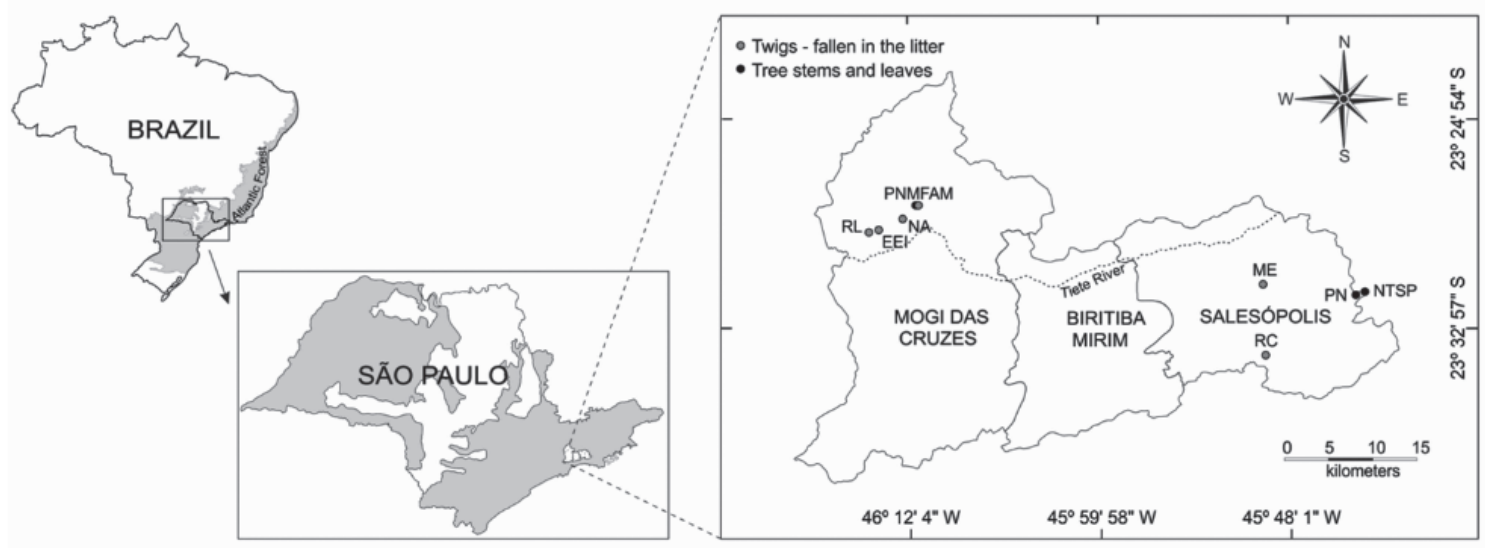

Fig. 1: Sampling sites. Fragments of the Atlantic Rainforest where the study was conducted.

Sitios de muestreo. Fragmentos de la Mata Atlántica donde se realizó el estudio. 
TABLE 1

Number of nests of Myrmelachista species present in the different species of trees.

Número de nidos de especies de Myrmelachista presentes en diferentes especies arbóreas.

\begin{tabular}{|c|c|c|c|c|c|c|c|}
\hline Taxon & $\begin{array}{c}M . \\
\text { ruszkii }\end{array}$ & $\begin{array}{c}M . \\
\text { catharinae }\end{array}$ & $\begin{array}{c}M . \\
\text { nodigera }\end{array}$ & $\begin{array}{c}\text { M. } \\
\text { arthuri }\end{array}$ & $\begin{array}{c}M . \\
\text { gallicola }\end{array}$ & $\begin{array}{l}\text { Myrmelachista } \\
\text { sp. } 4\end{array}$ & $\begin{array}{l}\text { Myrmelachista } \\
\text { sp. } 7\end{array}$ \\
\hline
\end{tabular}

Anacardiaceae

Schinus terebinthifolius Raddi

Arecaceae

Arecaceae sp. 1

Asteraceae

Piptocarpha macropoda (DC. Baker)

1

Asteraceae sp. 1

Asteraceae sp. 2

Cannabaceae

Trema micrantha (L.) Blume

Euphorbiaceae

Alchornea sidifolia Muell. Arg.

Fabaceae

Fabaceae sp. 1

Fabaceae sp. 2

Lauraceae

Aniba sp.1

Melastomataceae

Tibouchina mutabilis Cogn.

(Vell.) Cogn Cogn.

Melastomataceae sp. 1

Myrsinaceae

Rapanea sp. 1

1

Myrtaceae

Myrtaceae sp. 1

1

Piperaceae

Piperaceae sp. 1

Rubiaceae

Psychotria sp. 1

1

Psychotria suterella Muell. Arg.

Psychotria vellosiana Benth

Solanaceae

Solanum sp. 1

Malvaceae

Malvaceae sp. 1

1

Total number of nests

9

10

6

6

2 
TABLE 2

Reproductive winged forms of Myrmelachista observed over a year in the live trees. ${ }^{\star}$ Data from one nest kept in the laboratory.

Formas aladas reproductivas de Myrmelachista observadas a lo largo de un año en árboles vivos. *Datos de un nido mantenido en el laboratorio.

\begin{tabular}{|c|c|c|c|c|c|c|}
\hline \multirow[t]{2}{*}{ Month } & \multirow{2}{*}{$\frac{\text { M. gallicola }}{\hat{\sigma}}$} & \multirow{2}{*}{$\frac{\text { M. arthuri* }}{\hat{\sigma}}$} & \multicolumn{2}{|c|}{ M. sp. 7} & \multirow{2}{*}{$\frac{\text { M. ruszkii }}{\hat{\delta}}$} & \multirow{2}{*}{$\frac{\text { M. catharinae }}{\delta}$} \\
\hline & & & q & $\hat{\sigma}$ & & \\
\hline \multicolumn{7}{|l|}{ January } \\
\hline \multicolumn{7}{|l|}{ February } \\
\hline \multicolumn{7}{|l|}{ March } \\
\hline April & & & $\mathrm{x}$ & $\mathrm{x}$ & & \\
\hline \multicolumn{7}{|l|}{ May } \\
\hline \multicolumn{7}{|l|}{ June } \\
\hline \multicolumn{7}{|l|}{ July } \\
\hline August & & $\mathrm{x}$ & & & & \\
\hline September & $\mathrm{x}$ & $\mathrm{x}$ & $\mathrm{x}$ & $\mathrm{x}$ & $\mathrm{x}$ & \\
\hline October & & & $\mathrm{x}$ & $\mathrm{x}$ & $\mathrm{x}$ & $\mathrm{x}$ \\
\hline November & & $\mathrm{x}$ & & & & $\mathrm{x}$ \\
\hline December & & & & & & \\
\hline
\end{tabular}

(Table 2). Myrmelachista ruszkii Forel and $M$. catharinae Mayr were found on the greatest number of tree species followed by $M$. nodigera Mayr and M. arthuri Forel (Fig. 2). Only $M$. arthuri nests $(\mathrm{n}=6$; Table 1$)$ were recorded in live twigs of live trees. Nests of the other species were found only in the tips of dry twigs in live trees (nests = 35; Table 1). Surprisingly, M. gallicola nests were found in 14 twigs of a single Schinus terebinthifolius Raddi plant with dry tips. These colonies consisted of a queen, workers and immature individuals. Each tree nest observed only one species of Myrmelachista, but different individuals of the same tree species may be occupied by different Myrmelachista species, as was the case of Rapanea sp.1 (with four Myrmelachista species), Tibouchina mutabilis (Vell.) Cogn (three), Trema micrantha (L.) Blume (two), Piperaceae sp.1 (two), Psychotria sp.1 (two), Solanum sp.1 (two) and Malvaceae sp.1 (two) (Table 2).

Nests were also found in small dead trees (diameter at breast height $<15 \mathrm{~cm}$ ). These nests belonged to the species $M$. ruszkii ( $\mathrm{n}=$ 3), M. catharinae $(\mathrm{n}=3), M$. gallicola $(\mathrm{n}=2)$ and $M$. nodigera $(\mathrm{n}=1)$. Two $M$. arthuri nests were found in dead trees fallen in the trail. One nest was located in a $30 \mathrm{~cm}$ diameter $T$. mutabilis (Melastomataceae) trunk, and the length of the trunk region that was occupied by the colony was approximately $50 \mathrm{~cm}$. This trunk was maintained in the laboratory $\left(28 \pm 2{ }^{\circ} \mathrm{C}\right.$; $70 \pm 10 \%)$ to determine the time of emergence of winged individuals (Table 2; Fig. 3). The other nest remained in the forest, and the tree species in which it was located could not be identified. Moreover, the presence of a single $M$. nodigera nest in a partially dry Psychotria sp.1 (Rubiaceae) trunk fallen in the litter was also recorded. Approximately 300 workers, several immature individuals and a single queen were collected in this nest.

The presence of winged individuals in live tree was recorded for some Myrmelachista species, and the reproductive period mainly occurred from August to December (Table $3)$. The number of winged individuals could only be counted for Myrmelachista sp. 7; 109 unfertilized queens and 11 males were found in one nest, while 113 unfertilized queens and only one male were found in the other nest.

A total of 33 nests, 19 of $M$. ruszkii and 14 of $M$. catharinae, were collected in twigs in 


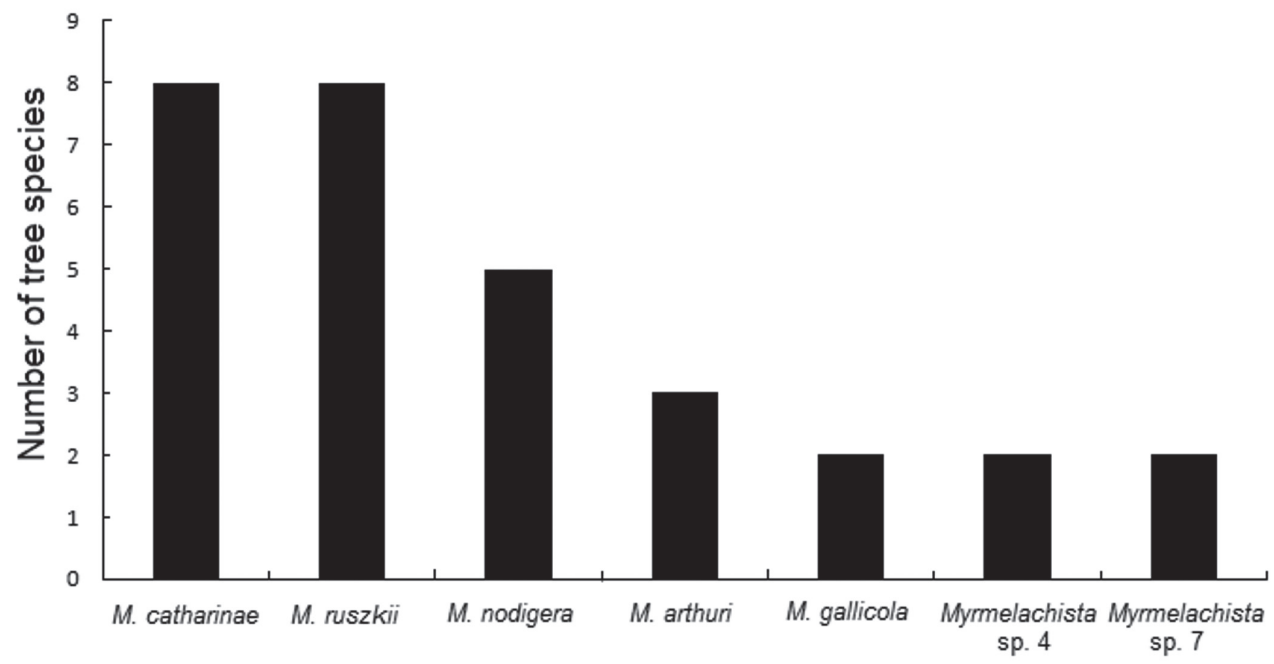

Fig.2: Total number of tree species associated with each studied Myrmelachista species in the Atlantic Forest of southeastern Brazil.

Número total de especies arbóreas asociadas a cada especie estudiada de Myrmelachista en la Floresta Atlántica del sudeste de Brasil.
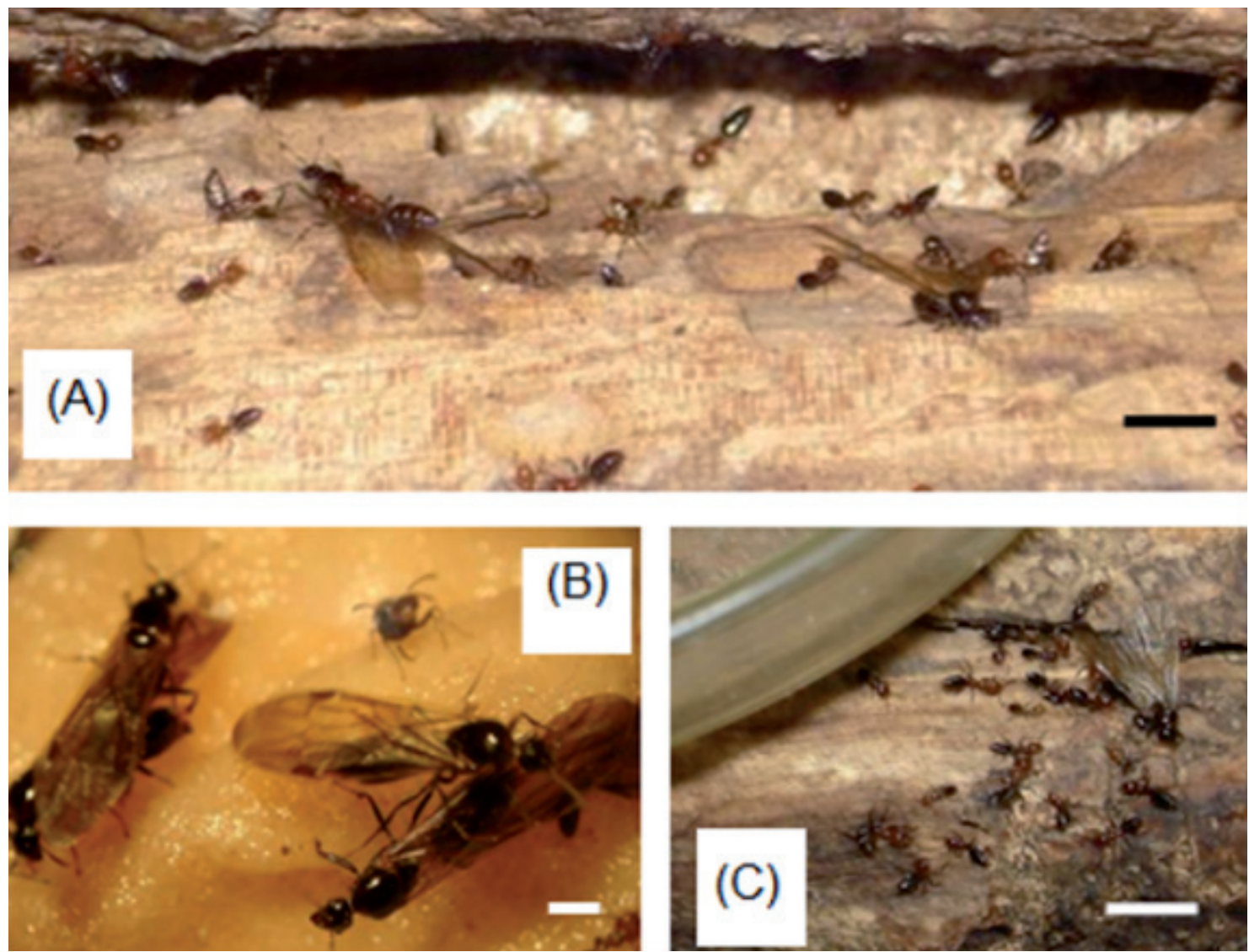

Fig. 3: Breeders of (ठ) de Myrmelachista arthuri. Scale: A y C $=1 \mathrm{~cm}, \mathrm{~B}=1 \mathrm{~mm}$.

Formas reproductoras aladas $(\widehat{)})$ de Myrmelachista arthuri. Escala: $\mathrm{A}$ y $\mathrm{C}=1 \mathrm{~cm}, \mathrm{~B}=1 \mathrm{~mm}$. 
TABLE 3

Total number of nests, workers and immature individuals of Myrmelachista in dry twigs. The data are reported as medians with the range in parentheses.

Número total de nidos, obreras e individuos inmaduros de Myrmelachista en ramas secas. Los datos corresponden a las medianas, los intervalos se muestran entre paréntesis.

\begin{tabular}{lcccc}
\hline & M. ruszkii & M. catharinae & test & $\mathrm{P}$ \\
\hline Nests & 19 & 14 & & \\
Workers & $28(9-458)$ & $58.5(13-349)$ & $\mathrm{U}=112$ & 0.44 \\
Immature & $58(5-330)$ & $55(6-537)$ & $\mathrm{U}=122.5$ & 0.70 \\
\hline
\end{tabular}

TABLE 4

Angiosperm families and species observed to associate with Myrmelachista species according to the literature.

Familias y especies de angiosperma observadas y asociadas con especies de Myrmelachista de acuerdo con la literatura.

\begin{tabular}{|c|c|c|}
\hline Family & Species & Reference \\
\hline Araucariaceae & Araucaria angustifolia (Bert.) O. Ktze & Ketterl et al. (2003) \\
\hline Bignoniaceae & Tabebuia sp. & Kusnezov (1951) \\
\hline \multirow[t]{7}{*}{ Boraginaceae } & Cordia alliodora (Ruiz \& Pavon) Oken & Longino (2006) \\
\hline & Cordia hispidissima A. de Candolle & Wheeler (1934) \\
\hline & Cordia nodosa Lamark & Davidson \& McKey (1993) \\
\hline & & Edwards et al. (2009) \\
\hline & & Frederickson \& Gordon (2009) \\
\hline & & Goitía \& Jaffé (2009) \\
\hline & & Frederickson \& Gordon (2009) \\
\hline \multirow[t]{6}{*}{ Bromeliaceae } & Canistrum sp. & Rosumek et al. (2008) \\
\hline & Nidularium sp. & Rosumek et al. (2008) \\
\hline & Tillandsia sp. & Benzing (1970) \\
\hline & Tillandsia balbisiana Schultes & Wheeler (1934) \\
\hline & Tillandsia circinnata Schlecht & Wheeler (1934) \\
\hline & Tillandsia valenzuelana A. Richard & Wheeler (1934) \\
\hline \multirow[t]{3}{*}{ Cecropiaceae } & Cecropia angustifolia Trécul. & Longino (2006) \\
\hline & Cecropia insignis Liebm. & Longino (2006) \\
\hline & Cecropia obtusifolia Bertol. & Longino (2006) \\
\hline Chrysobalanaceae & Licania pittieri Prince & Goitía \& Jaffé (2009) \\
\hline \multirow[t]{3}{*}{ Clusiaceae } & Calophyllum brasiliense Camb. & Longino (2006) \\
\hline & Clusia alata Planch. & Longino (2006) \\
\hline & Vismia sp. & Longino (2006) \\
\hline Elaeocarpaceae & Sloanea sp. & Longino (2006) \\
\hline \multirow[t]{2}{*}{ Euphorbiaceae } & Croton floribundus (L.) Spreng. & Morini et al. (2006) \\
\hline & Euphorbia pulcherrima Wildenow & Haber et al. (1981) \\
\hline
\end{tabular}


TABLE 4. Continuation

\begin{tabular}{|c|c|c|}
\hline Family & Species & Reference \\
\hline & Sapium oligoneurum K. Schum. & Longino (2006) \\
\hline \multirow[t]{10}{*}{ Fabaceae } & Acacia aroma Gill. Ex Hook et Arn & Quirán \& Martínez (2006) \\
\hline & Acacia caven (Mol.) Mol. & Quirán \& Martínez (2006) \\
\hline & Anadenanthera macrocarpa Benth & Campos et al. (2006) \\
\hline & Erythrina sp. & Longino (2006) \\
\hline & Inga sp. & Goitía \& Jaffé (2009) \\
\hline & & Longino (2006) \\
\hline & Lonchocarpus sp. & Longino (2006) \\
\hline & Prosopis caldenia Burkart & Quirán \& Martínez (2006) \\
\hline & Prosopis nigra (Griseb.) & Quirán \& Martínez (2006) \\
\hline & Prosopis ruscifolia (Vinal) & Kusnezov (1951) \\
\hline Fagaceae & Nothofagus antarctica (G.Forster) Oerst & Kusnezov (1951) \\
\hline \multirow[t]{7}{*}{ Lauraceae } & Licaria sp. & Hanson \& Longino (2006) \\
\hline & & Longino (2006) \\
\hline & Ocotea spp. & $\begin{array}{c}\text { Stout (1979) } \\
\text { Hammel (1986) }\end{array}$ \\
\hline & & Longino (2006) \\
\hline & & McNett et al. (2010) \\
\hline & Ocotea austinii CK Allen & Longino (2006) \\
\hline & Pleurothyrium sp. & Davidson et al. (1989) \\
\hline Malvaceae & Hampea appendiculata (Donn. Smith) Standl & Longino (2006) \\
\hline \multirow[t]{7}{*}{ Melastomataceae } & Clidemia heterophylla (Desr.) Gleason & Renner \& Ricklefs (1998) \\
\hline & Conostegia sp. & Longino (2006) \\
\hline & Miconia sp. & Hanson \& Longino (2006) \\
\hline & Pterocladon spruce Hook. F. & Wheeler (1934) \\
\hline & Tibouchina mutabilis (Vell.) Cogn. & Morini et al. (2006) \\
\hline & Tococa guianensis Aubl. & Morawetz et al. (1992) \\
\hline & & Renner \& Ricklefs (1998) \\
\hline \multirow[t]{3}{*}{ Meliaceae } & Carapa guianensis Aubl. & Longino (2006) \\
\hline & Guarea sp. & Hanson \& Longino (2006) \\
\hline & Guarea rhopalocarpa Radlk. & Longino (2006) \\
\hline Moraceae & Ficus sp. & Longino (2006) \\
\hline Myristicaceae & Virola sp. & Edwards et al. (2009) \\
\hline \multirow[t]{7}{*}{ Rubiaceae } & Borreria verticillata (L.) G. Mey & Wheeler (1934) \\
\hline & Coffea arabica $\mathrm{L}$. & Armbrecht \& Gallego (2007) \\
\hline & & Philpott et al. (2006) \\
\hline & Duroia hirsute (Poeppig \& Endl) Schumann. & Davidson \& McKey (1993) \\
\hline & & Frederickson et al. (2005) \\
\hline & & Frederickson \& Gordon (2009) \\
\hline & Palicourea sp. & Longino (2006) \\
\hline Tiliaceae & Hasseltia floribunda Kunth. & Haber et al. (1981) \\
\hline Urticaceae & Pourouma sp. & Edwards et al. (2009) \\
\hline
\end{tabular}


the litter (Table 4), all of which were with a single queen. Winged ants were recorded only in four colonies, three of $M$. ruszkii and one of $M$. catharinae. The populations of workers and immature individuals in the $M$. ruszkii and $M$. catharinae colonies were not significantly different (Table 3). The canopy openness was associated with the number of nests in the leaf litter $\left(\mathrm{r}_{\mathrm{S}}=-0.4151 ; \mathrm{P}=0.02\right)$ (Fig. 4)

\section{DISCUSSION}

The seven Myrmelachista species recorded in the studied Atlantic Forest remnants complement the existing data on ant biodiversity in the region (Suguituru et al. 2011, 2013) and the tree species in which nests of this ant genus can be found (Table 4).

The species richness that was found is relevant for biodiversity studies because workers are rarely observed foraging on the surfaces of plants (Longino 2006); as a consequence, species records are rare or even absent in studies on arboreal ants (Silvestre et al. 2003, Morini et al. 2006, Delabie et al. 2007).

Most of the nests found in the vegetation were located in the tips of dry twigs of live trees or in dead trunks of trees; few nests were found in live stems. Nevertheless, most Myrmelachista species nest in cavities or live stems of trees (Stout 1979, Brown 2000, Longino 2006, Edwards et al. 2009).

Myrmelachista nests are also found in dry twigs fallen in the litter but are more abundant in areas with open canopies. For other ant species recorded in dry twigs in the Atlantic Forest, the abundance of nests increases with canopy cover (Fernandes et al. 2012), as there is a greater supply of resources (Philpott \& Foster 2005). Most nests in dry twigs recorded by Nakano et al. (2012) in sunny trials belonged to $M$. catharinae and $M$. ruzkii, which corroborates the present work. In addition, five species that occur at the tips of dry twigs of live

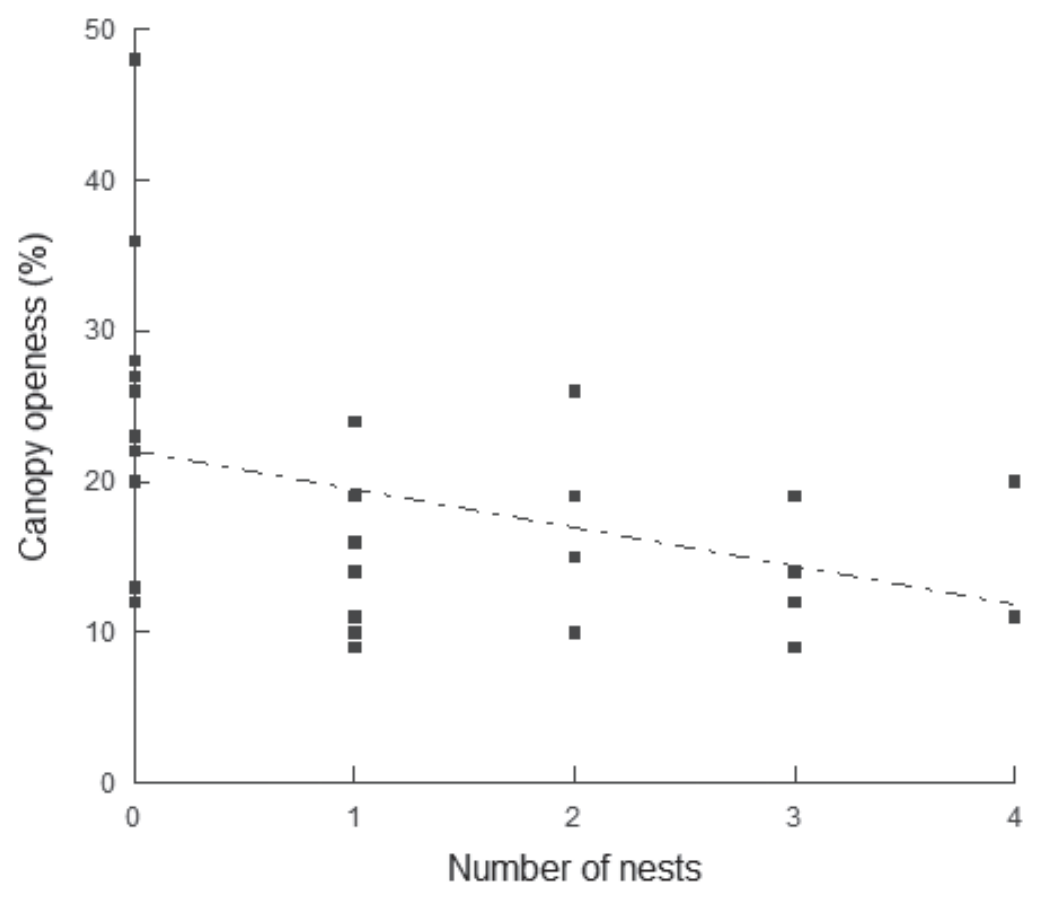

Fig. 4: Association between canopy cover and the number of nests in twigs in the Atlantic Forest of southeastern Brazil.

Asociación entre cobertura del dosel y el número de nidos en ramas pequeñas en la Floresta Atlántica del sudeste de Brasil 
trees are found in dry twigs fallen on the litter (Nakano et al. 2012).Exception is made for $M$. arthuri that was recorded in this work only in live stems, but not in fallen twigs on the litter (Nakano et al. 2012).

Thus, it is likely that the some Myrmelachista species found in this study have a preference for nesting in drier microhabitats and that the twigs inhabited by ants in the litter originated from the trees listed in Table 1 , which housed the colony with the queen and winged individuals at the time at which the twigs fell to the ground. This fact is supported (1) by the observation made in this study for M. gallicola and also by Ketterl et al. (2003), who found the presence of three Myrmelachista species in Araucaria angustifolia (Bertol.) Kuntze, both in trees and nearby fallen twigs, and (2) because the most frequently observed Myrmelachista species in tips of dry twigs of live trees are the same as those found nesting in twigs on the litter surface. Conversely, the fact that only $M$. catharinae and $M$. ruszkii nests were found in dead twigs fallen in the litter is interesting because other species (Myrmelachista sp. 4; Myrmelachista sp. 7; M. nodigera and $M$. gallicola) were recorded in the tips of dry twigs. Morever, Nakano et al. (2012) reported Myrmelachista sp. 4, M. catharinae, $M$. ruszkii, $M$. nodigera, $M$. gallicola, and $M$. reticulata in fallen twigs in the leaf litter of the sunny Atlantic Forest.

Specifically for $M$. gallicola, the 14 nests found in a single plant suggest a possible case of polydomy because all of the nests had workers, immature individuals and one fertilized queen (Debout et al. 2007, Lanan et al. 2011). However, no connection was found among them, corroborating the results of Carvalho \& Vasconcelos (2002), Santos \& Del Claro (2009) and Lanan et al. (2011). Polydomy is relatively common among ants, occurring in over 150 species (Debout et al. 2007).

The occurrence of polydomy may be an alternative for Myrmelachista colonies possessing growth that may be limited by the space available for nesting, but polydomy may also be related to polygyny (Walin et al. 2001), increased foraging area (Santos \& Del Claro 2009, Schmolke 2009, Lanan et al. 2011), offspring thermoregulation (Pedersen \& Boomsma 1999) and type of food source, such as extrafloral nectaries and insect exudates in the case of Myrmelachista (Pfeiffer \& Linsenmair 1998). Myrmelachista also uses other food sources external to the host plant (McNett et al. 2010). M. ramulorum Wheeler workers, for example, were observed carrying plant and animal parts (eggs, feces and larvae), and even fungi, into their nest (Torres 1984). The workers of $M$. arthuri kept in the laboratory collected insect pieces (cockroaches and termites) and carried them into the nest (Nakano MA personal obs.).

When disturbed, due to a more abrupt motion of the researcher, while foraging or at the nest entrance, individuals of $M$. ruszkii, M. catharinae, M. arthuri and Myrmelachista sp. 7 responded aggressively, immediately elevating their gaster. Conversely, individuals of $M$. nodigera, M. gallicola and Myrmelachista sp. 4 quickly hid in nest holes. The aggressive behavior of gaster elevation has been previously observed for M. zeledoni Emery (Longino 2006) and Myrmelachista sp. (Espírito Santo 2008). Davidson et al. (1989) described a less aggressive behavior for another unidentified species.

The natural history of most ant species is still poorly understood, preventing broad generalizations (Del-Claro et al. 2009). This study partly fills the gap in the body of knowledge regarding the biology of the genus Myrmelachista by reporting observations concerning a number of its species, such as the ability of colonies to emergence winged reproductives especially during rainy season, that is an important stimulus for the synchronized release of winged ants (Torres et al. 2001; Santos \& Del Claro 2009). This result complements the work of Nakano et al. (2012) that reported the emergence of males and females of Myrmelachista during rainy season and the confirmation of $M$. ruszkii and $M$. catharinae as common species in Atlantic Forest remnants of southeastern Brazil. Furthermore, this study reports the preference of these species for sites with opener canopies.

ACKNOWLEDGEMENTS: The authors would like to thank the National Council for Scientific and Technological Development (Conselho Nacional de Desenvolvimento Científico e Tecnológico, $\mathrm{CNPq}$ ) for the scholarships that were granted to MA Nakano (grant 132485/2008-7) and MSC Morini (grant 301151/2009-1), the São Paulo Research Foundation (FAPESP) for aid to RM Feitosa (grant 07/01310-2) and MSC Morini (grant 10/50294- 
2) and Prof. Dr. CRF Brandão for making valuable suggestions.

\section{LITERATURE CITED}

ARMBRECHT I \& MC GALLEGO (2007) Testing ant predation on the coffee berry borer in shaded and sun coffee plantations in Colombia. Entomologia Experimentalis et Applicata 124: 261-267.

BENZING DH (1970) An investigation of two bromeliad myrmecophytes: Tillandsia butzii Mez, T. caputmedusae E. Morren, and their ants. Bulletin of the Torrey Botanical Club (USA) 97: 109-115.

BOLTON B, G ALPERT, PS WARD \& P NASKRECKI (2006) Boltons's Catalogue of Ants of the World 1758-2005. Harvard University Press, Cambridge. CD-ROM.

BROWN WL (2000) Diversity of ants. In: Agosti D, JD Majer, Alonso LE \& TR Schultz (eds) Ants: standard methods for measuring and monitoring biodiversity: 45-79. Washington: Smithsonian Institution, Washington D.C., USA.

CAMPOS RI, HL VASCONCELOS, SP RIBEIRO, FS NEVES \& JP SOARES (2006) Relationship between tree size and insect assemblages associated with Anadenanthera macrocarpa. Ecography 29: 442-450.

CARVALHO KS \& HL VASCONCELOS (2002) Comunidade de formigas que nidificam em pequenos galhos da serapilheira em floresta da Amazônia Central, Brasil. Revista Brasileira de Entomologia 46: 115-121.

DAVIDSON DW \& D MCKEY (1993) Ant-plant symbioses: stalking the chuyachaqui. Trends in Ecology and Evolution 8: 326-332.

DAVIDSON DW, RR SNELLING \& JT LONGINO (1989) Competition among ants for myrmecophytes and the significance of plant trichomes. Biotropica 21: 64-73.

DEBOUT G, B SCHATZ, M ELIAS \& D MCKEY (2007) Polydomy in ants: what we know, what we think we know, and what remains to be done. Biological Journal of the Linnean Society 90: 319-348.

DELABIE JHC, B JAHYNY, IC NASCIMENTO, CSF MARIANO, S LACAU, S CAMPIOLO, S.M PHILPOTT \& M LEPONCE (2007) Contribution of cocoa plantations to the conservation of native ants (Insect: Hymenoptera: Formicidae) with a special emphasis on the Atlantic forest fauna of southern Bahia, Brazil. Biodiversity and Conservation (Netherlands) 16: 2359-2384.

DEL-CLARO K, HM TOREZAN-SILINGARDI, C BELCHIOR \& E ALVES-SILVA (2009) Ecologia Comportamental: uma ferramenta para a compreensão das relações animal-planta. Oecologia Brasiliensis (Brazil) 13: 16-29.

EDWARDS DP, ME FREDERICKSON, GH SHEPARD \& DW YU (2009) A plant needs ants like a dog needs fleas: Myrmelachista schumanni ants gall many trees species to create housing. American Naturalist 174: 734-740.

ESPÍRITO-SANTO NB (2008) Assembléia de formigas do Parque Estadual do Itacolomi (MG) e relações intra e interespecíficas entre espécies dominantes. Master's Dissertation, Institute of Biological Sciences, Federal University of Juiz de Fora.

FERNÁNDEZ F \& S SENDOYA (2004) List of Neotropical ants (Hymenoptera: Formicidae). Biota Colombiana 5: 3-93.
FERNANDES TT, RR SILVA, DR SOUZA, N ARAÚJO \& MSC MORINI (2012) Undecomposed twigs in the leaf litter as nest-building resources for ants (Hymenoptera: Formicidae) in areas of the Atlantic Forest in the southeastern region of Brazil. Psyche (Egypt) 2012: 1-8.

FRAZER GW, CD CANHAM \& KP LERTZMAN (1999) Gap Light Analyzer (GLA): Imaging software to extract canopy structure and gap light transmission indices from true-colour fisheye photographs, users manual and program documentation. Copyright (C) 1999: Simon Fraser University, Burnaby, British Columbia, and the Institute of Ecosystem Studies, Millbrook, New York.

FREDERICKSON ME (2005) Ant species confer different partner benefits on two neotropical myrmecophytes. Oecologia 143: 387-395.

FREDERICKSON ME (2006) The reproductive phenology of an Amazonian ant species reflects the seasonal availability of its nest sites. Oecologia 149: 418-427.

FREDERICKSON ME, DM GORDON \& M J GREENE (2005) “Devil's gardens" bedeviled by ants. Nature 437: 495-496.

FREDERICKSON ME \& DM GORDON (2009) The intertwined population biology of two Amazonian myrmecophytes and their symbiotic ants. Ecology 90: 1595-1607.

GOITÍA W \& K JAFFÉ (2009) Ant-plant associations in different forests in Venezuela. Neotropical Entomology 38: 7-31.

HABER WA, GW FRANKIE, HG BAKER, I BAKER \& S KOPTUR (1981) Ants like flower nectar. Biotropica 13: 211-214.

HAMMEL BE (1986) The vascular flora of La Selva Biological Station, Costa Rica - Lauraceae. Selbyana 9: 218-233.

HANSON PE \& JT LONGINO (2006) Hormigas (Formicidae). In: Hanson PE \& ID Gauld (eds) Hymenoptera de la región neotropical: 617644. Gainesville: Memoirs of the American Entomological Institute, Florida, USA.

KEMPF WW (1972) Catálogo Abreviado das Formigas da Região Neotropical. Studia Entomologica (Brazil) 15: 3-344.

KETTERL J, M VERHAAGH, JH BIHN, CRF BRANDÃO \& W ENGELS (2003) Spectrum of ants associated with Araucaria angustifolia trees and their relations to hemipteran trophobionts. Studies on Neotropical Fauna Environment (Germany) 38: 199-206.

KUSNEZOV N (1951) Myrmelachista en la Patagonia (Hymenoptera, Formicidae). Acta Zoologica Liloana (Argentina) 11: 353-365.

LANAN MC, A DORHAUS \& JL BRONSTEIN (2011) The function of polydomy: the ant Crematogaster torosa preferentially forms new nests near food sources and fortifies outstations. Behavioral Ecology and Sociobiology (Germany) 65: 959-968.

LONGINO JT 2006 A taxonomic review of the genus Myrmelachista (Hymenoptera: Formicidae) in Costa Rica. Zootaxa 1141: 1-54.

McNETT K, JT LONGINO, P BARRIGA, O VARGAS, K PHILLIPS, CL SAGERS (2010) Stable isotope investigation of a cryptic ant-plant association: Myrmelachista flavocotea (Hymenoptera: Formicidae) and Ocotea spp. (Lauraceae). Insect Sociaux (Belgium) 57: 67-72. 
MINUZZI RB, GC SEDIYAMA, EM BARBOSA \& JCF MELO JR (2007) Climatologia do comportamento do período chuvoso da região sudeste do Brasil. Revista Brasileira de Meteorologia (Brazil) 22: 338-344.

MORAWETZ W, M HENZL \& B WALLNOFER (1992) Tree killing by herbicide producing ants for the establishment of pure Tococa occidentalis populations in the Peruvian Amazon. Biodiversity and Conservation (Netherlands) 1: 19 - 33.

MORINI MSC, N KAMAZUKA, R LEUNG, SS SUGUITURU \& LF SILVA (2006) Ant fauna (Hymenoptera: Formicidae) in Magnoliophyta native to the Atlantic Forest. Sociobiology 47: 433-444.

NAKANO MA, RM FEITOSA, CO MORAES, LDC ADRIANO, EP HENGLES, LE LONGUI \& MSC MORINI (2012) Assembly of Myrmelachista Roger (Formicidae: Formicinae) in twigs fallen on the leaf litter of Brazilian Atlantic Forest. Journal of Natural History 46: 2103-2115

PEDERSEN JS \& JJ BOOMSMA (1999) Genetic analysis of colony structure in polydomous and polygynous ant populations. Biological Journal of the Linnean Society 66: 115-144.

PFEIFFER M \& KE LINSENMAIR (1998) Polydomy and the organization of foraging in a colony of the Malaysian giant ant Camponotus gigas (Hymenoptera, Formicidae). Oecologia 117: 579590.

PHILPOTT SM, S UNO \& J MALDONADO (2006) The importance of ants and high-shade management to coffee pollination and fruit weight in Chiapas, Mexico. Biodiversity and Conservation (Netherlands) 15: 487-501.

PHILPOTT SM \& PF FOSTER (2005) Nest-site limitation in coffee agroecosystems: artificial nests maintain diversity of arboreal ants. Ecological Applications 15: 1478-1485.

QUIRÁN EM \& JJ MARTÍNEZ (2006) Redescripción de la obrera de Myrmelachista gallicola (Hymenoptera: Formicidae) y primera cita para la provincial de La Pampa (Argentina). Revista de la Sociedad Entomológica Argentina (Argentina) 65: 89-92.

RENNER SS \& RE RICKLEFS (1998) Herbicidal activity of domatia-inhabiting ants in patches of Tococa guianensis and Clidemia heterophylla. Biotropica 30: 324-327.

Editorial responsibility: Marco A. Méndez

Received received June 12, 2012; accepted May 17, 2013
ROSUMEK FB, MA ULYSSEA, BC LOPES, J STEINER \& A ZILLIKENS (2008) Formigas de solo e de bromélias em uma área de Mata Atlântica, Ilha de Santa Catarina, sul do Brasil: levantamento de espécies e novos registros. Biotemas 21: 81-89.

SANTOS JC \& K DEL-CLARO (2009) Ecology and behaviour of the weaver ant Camponotus (Myrmobrachys) senex. Journal of Natural History 43: 1423-1435.

SCHMOLKE A (2009) Benefits of dispersed centralplace foraging: an individual-based model of a polydomous ant colony. American Naturalist 173: $772-778$.

SILVESTRE R, CRF BRANDÃO \& RR SILVA (2003) Grupos funcionales de hormigas: el caso de los grêmios del Cerrado. In: Fernández F (ed) Introducción a las hormigas de la región Neotropical: 113-148. Instituto de Investigatión de Recursos Biológicos Alexander Von Humboldt, Colômbia.

STOUT J (1979) An association of an ant, a mealy bug, and an understory tree from a Costa Rican rain forest. Biotropica 11: 309-311.

SUGUITURU SS, RR SILVA, DR SOUZA, CB MUNHAE, MSC MORINI (2011) Ant community richness and composition across a gradiente from Eucalyptus plantations to secondary Atlantic Forest. Biota Neotropica (Brazil) 11:1-8.

SUGUITURU SS, DR SOUZA, CB MUNHAE, R PACHECO, MSC MORINI (2013) Diversidade e riqueza de formigas (Hymenoptera: Formicidae) em remanescentes de Mata Atlântica na Bacia Hidrográfica do Alto Tietê, SP. Biota Neotropica (Brazil) 13:1-8.

TORRES JA (1994) Niches and coexistence of ant communities in Puerto Rico: Repeated patterns. Biotropica 26: 124-140.

TORRES JA, RR SNELLING \& M CANALS (2001) Seasonal and nocturnal periodicities in ant nuptial flights in the tropics (Hymenoptera: Formicidae). Sociobiology 37: 601-626.

WALIN L, P SEPPA \& L SUNDSTROM (2001) Reproductive allocation within a polygyne, polydomous colony of the ant Myrmica rubra. Ecological Entomology 26: 537-546.

WHEELER WM (1934) Neotropical ants collected by Dr. Elisabeth Skwarra and others. Bulletin of the Museum of Comparative Zoology (USA) 77: $157-240$. 
